\title{
THE EFFECT OF COMPETENCE, INDEPENDENCE AND WORKLOAD ON AUDIT QUALITY
}

\author{
Didit Darmawan ${ }^{1}$ \\ Ella Anastasya Sinambela ${ }^{2}$ \\ Nur Ika Mauliyah ${ }^{3}$ \\ ${ }^{1,2}$ Universitas Mayjen Sungkono Mojokerto \\ ${ }^{3}$ Universitas Islam Balitar Blitar \\ *dr.diditdarmawan@gmail.com
}

\begin{abstract}
One indicator of quality actions in management and company is the assessment of financial reports through audit actions. In every audit action is always expected to give qualified results based on the conclusions and opinions objectively. The auditor becomes the prominant determinant of how the results of an audit action can be answerable. The competency, independency and workload become a causal variable of an auditor behavior's perspective on audit quality. The purpose of this study is analyzing and determining the effect of partial and simultaneous competency, independency, and workload on audit quality and knowing which independent variables which have a significant effect on audit quality. The study involved 66 respondents. Then the collected data is analyzed by multiple regression and using SPSS which has been tested by validity, reliability test, and classical assumption test. The results of this study proves that there is a positive and significant influence partially and simutaneously from a competency variable, independency and workload on audit quality. The independency becomes a dominant variable which influence audit quality.
\end{abstract}

Keywords: audit quality; competency; independency; workload.

Received: 10 August, 2017; Accepter: 10 September, 2017

\section{INTRODUCTION}

Audit plays an important role to develop the business sector of the business enterprise. Audit is required due to the limited liability of the owners of the company, so as to ensure that external users can rely on and compare information released between companies, the information should be reliable. By increasing the reliability of information, auditing is a prerequisite for a well-functioning business and community life. By conducting an audit, the company ensures that they have quality in management and corporate actions because of the role of auditors to ensure quality for external users and companies. Audit has a role to secure the quality for external users. That explanation clarify the importance of auditing and demonstrates that it is also done to provide information to more users than external owners. External users include users such as creditors, customers, suppliers and the public. Thus the 
audit action will determine the response of the parties related to the survival of the company next.

The audit is carried out by the party which has standardized competence and has received sufficient technical training as an auditor. Competence as an auditor is obtained through education, continuing training and sufficient experience to audit. Beside the competence, the auditor must also have the independence to conduct audit actions in order to provide opinions or conclusions objectively as it is without any influences from the parties concerned about the audit results. Competence and independence is a standard that must be met by an auditor to be able to audit well.

Auditors play an important role in the fairness of financial. It is important for financial users that the data which reported has been correctly measured, and reasonably indicated. Auditors should enhance their ability to increase the probability of relying on audited reports and audited financial report that are more relevant, unbiased and accurate for decision makers. Many things can affect audit quality such as auditor qualification, company's internal control system, firm audit size, reputation and so on.

Thus competence and independence become the variable cause from the viewpoint of auditor behavior (Lee and Stone, 1995). In addition, another factor that is quite decisive is the workload. It is natural that the auditors have so many clients. They have tight and busy time schedules and often work in under pressure situation. This will bring up the workload that may affect the effectiveness and efficiency of work so that it can be influence the quality of the work result.

Based on the problems mentioned above, the writer is interested in carrying out a study on"Influence of competence, independence and workload on audit quality."

\section{Review of Literature Quality Audit}

Auditing is an activity of collecting and assessing evidences, supporting the quantitative information of an entity to determine and report the extent of conformity between the quantitative information with predetermined criteria so as to provide conclusions on the fairness of the presentation of accountability, as well as ensuring compliance with laws, policies and regulations through testing whether organizational and program activities are managed economically, efficiently and effectively. Audits should be conducted by competent and independent institutions or individuals (Hebert, 2005; Arrens and Loebbecke, 2012).

Practically, the quality of the audit leads to the results of the audit of financial report. According to DeAngelo (1981) the quality level of the audit service is determined by the accuracy of finding violations in the client's accounting system (if any) and reporting the violation. In addition, quality of audit levels are also demonstrated through the level of expertise in client information systems, strong commitment, not always trusting clients, and being able to take a decision to provide objective opinions.

\section{Competence}

In his scientific studies, Lee and Stone (1995) define competence as an adequate skill that can explicitly be used to audit objectively. The existence of adequate skills includes personal aspects of a person to achieve performance. These personal aspects include the nature, 
motives, value system, attitudes, knowledge and skills in which the competence will lead to his subsequent behavior determining performance.

The competence of an auditor is absolutely necessary to audit. Definition of competence in the field of auditing is often measured by knowledge and experience. Competence is tested from the knowledge and experience possessed. A knowledgeable auditor supported by sufficient experience will know and understand more and more deeply and easily to keep up with the more complex developments in the client's audit environment. This means that with the competence of auditors they will be better to provide a rational explanation when identifying mistakes in the client's financial reports and able to classify mistakes based on audit objectives and also on the structure of the underlying accounting system (Libby and Frederick, 1990) .

\section{Independence}

Auditor independence is the ability of the auditor to act objectively and have integrity and if there is a certain relationship with the client, it will cause the third party to doubt his ability as an auditor because of his allegiance (Kwambo, 2009). The independence of an auditor refers to its ability to produce audits in accordance with applicable standards. The auditor must be free from the influence of others to carry out the audit. Thus, audit quality is influenced significantly by auditor independence (Ionescu, 2016). The existence of the independence factor will cause the public to trust the audit quality generated by the auditor.

The problem is the auditor's independence is preoccupied with its position against the client. The potential of auditors follow the client's because they are paid by the client, even independence is threatened to disappear because of it. This is consistent with the statement by Deis and Giroux (1992) which states that there is a power conflict where clients can suppress the auditor against professional standards and the main thing is to impose a healthy client's financial condition can be used as a tool to suppress the auditor by making threat of auditor change.

The workload of an auditor is seen from the number of clients it handles or the limited time available to carry out the audit process. The high workload can cause fatigue and the emergence of difunctional audit so as to reduce the accuracy and ability of the auditor to find errors or report irregularities. According to Hansen et al. (2007) the decrease in audit quality is the result that is raised due to audit accompanied by work load. Findings Lopez (2005) states that the result of the audit process conducted when there is pressure of workload is lower audit quality than when there is no pressure on the workload.

A person who has a high workload cause a growing sense of personal achievement that is marked by low motivation and decreased feelings of competence and achievement (Cordes and Dougherty 1993). The worse effects of excessive workload can also cause auditors to break away from clients and colleagues, and develop an unfeeling and unconcerned attitude as a way to minimize their emotional investment in work (Jackson et al., 1986). Furthermore, according to McKee (2014), a person influenced by negative emotions significantly in general often focuses on these emotional sources exclusively rather than engaging in productive behavior. In this situation, the person does not process information correctly and does not think creatively, or make good decisions. Frustration, anger, and stress caused by workloads are a disadvantage for something related to sustainable quality. 


\section{Research Hypothesis}

The hypothesis in this study is determined as follows: (1) competence has a significant effect partially on audit quality; (2) independence has a significant partial effect on audit quality; (3) workload significantly partially affect the quality of audit; (4) competence, independency, and work load significantly influence the quality of audit; (5) independence has a significant influence predominantly on audit quality compared to other independent variables.

\section{Conceptual Framework}

This study was conducted to examine the effect of competence and independence on audit quality. The following of the framework research concept, as follows:

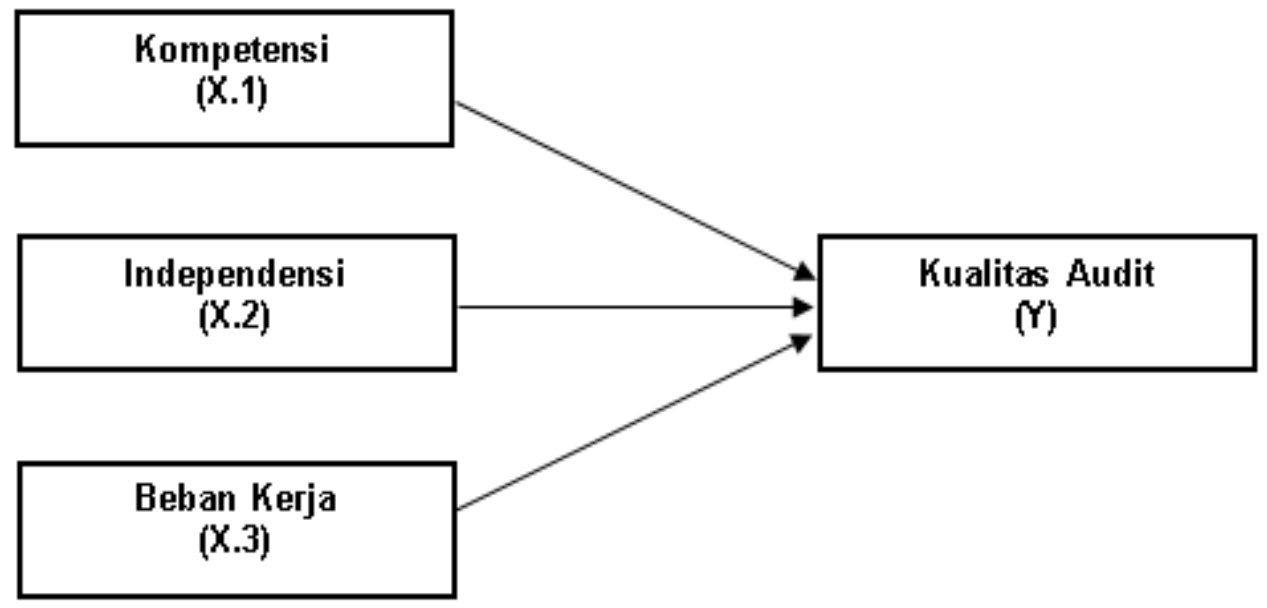

Picture 1

Conceptual framework

\section{RESEARCH METHODS}

The population is the public auditor in Surabaya. Respondents who used in this research were 66 people from 14 Public Accounting Firm. The process of distributing the questionnaires was done by letter to 14 Public Accounting Firm. One hundred questionnaires sent via mail, there were 66 pieces returned and then sampled. Thus the number of samples in the study were 66 public auditors.

The measurement of datas in this research are questionnaires or list of questionnaires arranged by theoretical grid in the form of Likerts scale with five rating scales. Analytical techniques that the authors do is to use inferential stastistik among other validity test, reliability test, classical assumption test, multiple regression analyst and $\mathrm{t}$ test and $\mathrm{F}$ test.

\section{RESULTS AND DISCUSSION}

Validity test aims to determine the extent to which the level of accuracy, precision and accuracy of measuring scale function in accordance with research objectives. If the measuring instrument can perform its function properly then the instrument can have a high degree of validity. In this research, the limit of each question item is valid if the corrected value of total correlation is greater than 0.3 . 
JARES, Vol. 2 No. 2 September, 2017; p-ISSN: 2502-826X; e-ISSN: 2503-1163

Copyrights@ Balitar Islamic University, Blitar, Indonesia; Http://jares.unisbablitar.ejournal.web.id Citation: Darmawan, Didit, et. al. 2017. The Effect of Competence, Independence and

Workload on Audit Quality. JARES, (2017), 2(2): 47-57

From the results SPSS data known that each item statement is more the limit of 0.3. Thus no question items were aborted from the original format. The conclusion is that each question item on the questionnaire is valid.

Table 1

Test of variable validity

\begin{tabular}{|c|c|c|c|}
\hline $\mathrm{No}$ & Variabel & $\mathrm{R}$ & Validitas \\
\hline 1 & X.1.1 & 0.598 & Valid \\
\hline 2 & X.1.2 & 0.619 & Valid \\
\hline 3 & X.1.3 & 0.359 & Valid \\
\hline 4 & X.1.4 & 0.375 & Valid \\
\hline 5 & X.2.1 & 0.304 & Valid \\
\hline 6 & X.2.2 & 0.543 & Valid \\
\hline 7 & $\mathrm{X} .2 .3$ & 0.565 & Valid \\
\hline 8 & X.2.4 & 0.362 & Valid \\
\hline 9 & X.2.5 & 0.640 & Valid \\
\hline 10 & X.2.6 & 0.621 & Valid \\
\hline 11 & X.2.7 & 0.481 & Valid \\
\hline 12 & X.3.1 & 0.573 & Valid \\
\hline 13 & X.3.2 & 0.597 & Valid \\
\hline 14 & X.3.3 & 0.539 & Valid \\
\hline 15 & Y.1.1 & 0.743 & Valid \\
\hline 16 & Y.1.2 & 0.796 & Valid \\
\hline 17 & Y.1.3 & 0.811 & Valid \\
\hline 18 & Y.1.4 & 0.840 & Valid \\
\hline 19 & Y.1.5 & 0.834 & Valid \\
\hline 20 & Y.1.6 & 0.743 & Valid \\
\hline 21 & Y.1.7 & 0.743 & Valid \\
\hline
\end{tabular}

Processed sources of SPSS

Reliability is a tool used to determine the level of reliability of the measuring tool. The higher the reliability value then the measuring tool used is also more reliable for use in further research or different places. The method used is with the determination of the alpha value above 0.6 .

Table 2

Test of Reliability

\begin{tabular}{|c|c|c|c|}
\hline No & Variabel & Alpha & Reliabilitas \\
\hline 1 & X.1 & 0.699 & Reliabel \\
\hline 2 & X.2 & 0.774 & Reliabel \\
\hline 3 & X.3 & 0.737 & Reliabel \\
\hline 4 & Y & 0.934 & Reliabel \\
\hline
\end{tabular}

Processed sources of SPSS

The result of reliability indicate that the value of the reliability coefficient of each variable is greater than 0.6. Thus the results of respondents' answers can be relied upon. This indicates that if the same research is done at different times then respondents will give the same answer. 
The normality test is to know the distribution of data from the formation of a regression model. Regression model is good if the data in the research has a normal or near normal distribution of data. One way to look at normality is to look at a normal probability plot. The results of SPSS shown in Figure 2 can be said that the graph shows spots that spread around the diagonal or normal line, and its distribution follows the direction of the diagonal line. Thus the resulting regression model is feasible to use.

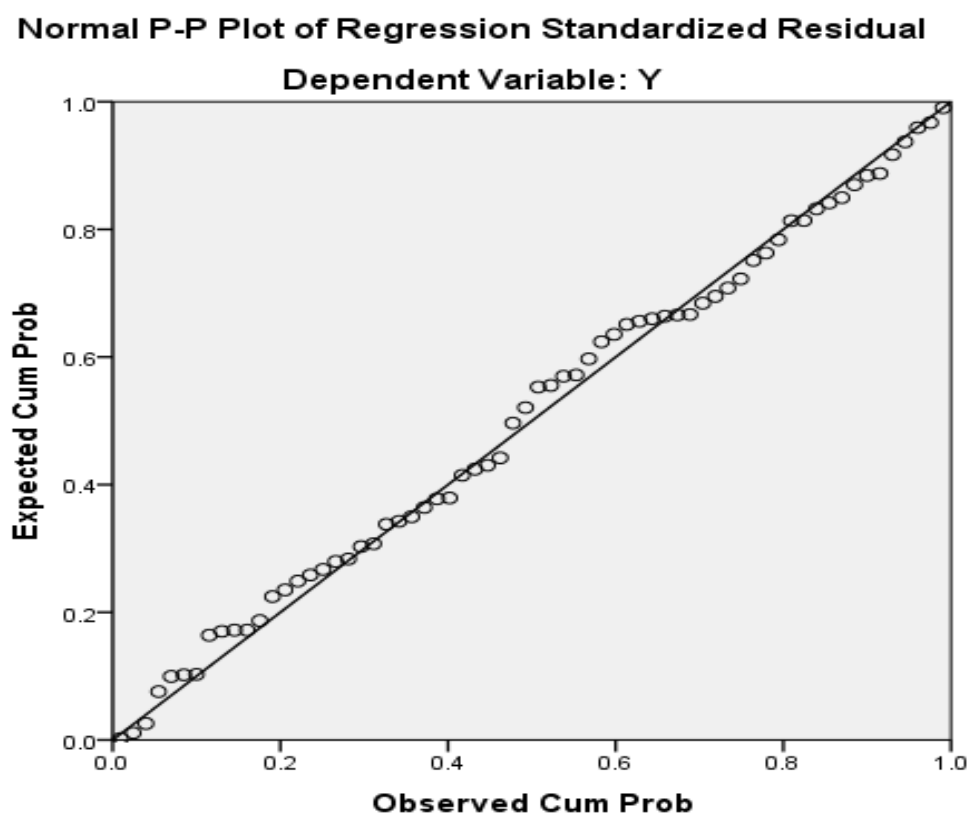

Picture 2

Distribution of normal data Processed sources of SPSS

Autocorrelation can change between several factors sorted by time (as in time series data) or space (some data). To see whether there is a problem of autocorrelation by means of statistics from Durbin-Watson.

Table 3

Durbin-Watson

Summary of summary

\begin{tabular}{|c|c|}
\hline Model & Durbin-Watson \\
\hline 1 & $2.064^{\mathrm{a}}$ \\
\hline
\end{tabular}

a. Predictors: (Constant), X.3, X.2, X.1

b. Dependent Variable: Y

Processed sources of SPSS

SPSS calculation results obtained by the writer obtained Durbin-Watson around 2.064 as in Table 3. The value is located at $1.01 \mathrm{~s} / \mathrm{d} 2.46$ which means the regression model in this research free of autocorrelation. 
The heteroscedasticity test aims to test whether in the regression model there is a variance inequality of the residual one observation to another. The trick is to observe the scatterplot on the dependent variable. Figure 3 shows the points on the scatterplot scattered and located on each section on the $\mathrm{Y}$ axis. Thus it can be concluded that there is no heteroscedasticity.

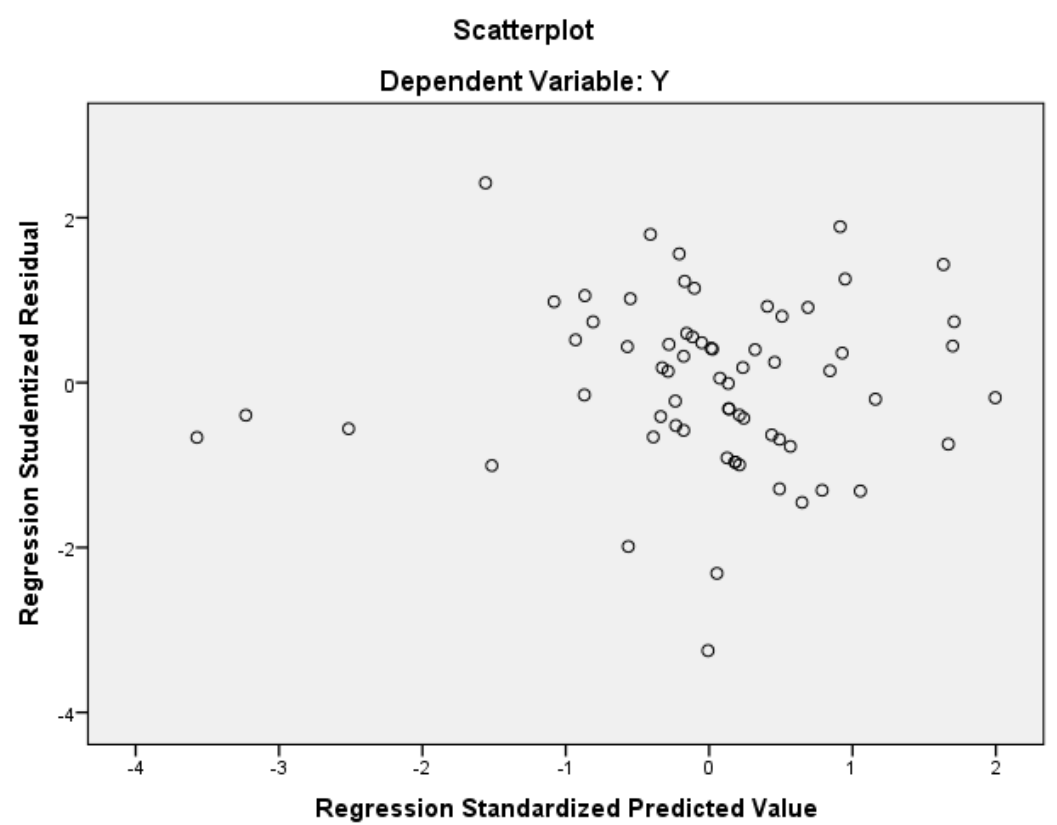

Picture 3

Scatterplot Dependent Variable Processed sources of SPSS

The tests on multicollinearity to determine whether the independent variables are not correlated or there is a linear relationship between the independent variables in the regression model used. Detecting Multicollinearity is by using Pearson correlation test. When the correlation coefficient is significant, then this means that the independent variable occurs Multicollinearity can also be seen from the value of tolerance and VIF values obtained. If the tolerance values obtained are less than 1 and VIF between 1 and 2 then the equation of a research model does not show the symptoms of Multicollinearity.

Table 4

Multikolonierity of Variabel

\begin{tabular}{|c|c|c|}
\hline \multirow{2}{*}{ Model } & \multicolumn{2}{|c|}{ Collinearity Statistics } \\
\cline { 2 - 3 } & Tolerance & VIF \\
\hline X.1 & .651 & 1.536 \\
\hline X.2 & .660 & 1.515 \\
\hline X.3 & .980 & 1.020 \\
\hline
\end{tabular}

a. Dependent Variable: Y

Source: Output result of SPSS 
Table 4 shows the tolerance values obtained less than 1 and the VIF values between 1 and 2. Thus it can be stated that the model equation of this study does not show symptoms of multicollinearity.

The next stage is testing of hypothesis. There are five hypotheses to prove the truth. With F test used to test the simultaneous influence of independent variable that is competence, independency and work load to audit quality. Test F is done by comparing the value of P.Sig with a limit of 0.05 . The calculation results using SPSS software as shown in Table 5 below.

Table 5

ANOVA $^{\mathrm{a}}$

\begin{tabular}{|l|c|r|r|r|r|}
\hline Model & $\begin{array}{c}\text { Sum of } \\
\text { Squares }\end{array}$ & df & Mean Square & F & Sig. \\
\hline $1 \quad$ Regression & 807.097 & 3 & 269.032 & 23.587 & $.000^{\mathrm{b}}$ \\
\hline Residual & 707.160 & 62 & 11.406 & & \\
\hline Total & 1514.258 & 65 & & & \\
\hline
\end{tabular}

a. Dependent Variable: Y

b. Predictors: (Constant), X.3, X.2, X.1

Processed sources of SPSS

Based on the results of the F test conducted by comparing the Probability Sig value. with a specified limit of 0.05 . From the comparison of P Sig. in Table 5 obtained a value of 0.000 which means it is under limit of 0.05 . Thus it can be stated that at the level of real $\alpha=$ 0.05 , competence, independence and workload have a significant effect simultaneously on audit quality. The hypothesis that competence, independence and work load have simultaneous influence on audit quality is proven true.

$\mathrm{T}$ test is used to test the partial influence of independent variable that is competence, independency and workload to audit quality as dependent variable. The calculation results using SPSS software as shown in table 6 below.

Table 6

Coefficients $^{\mathrm{a}}$

\begin{tabular}{|c|c|c|c|c|c|}
\hline \multirow[b]{2}{*}{ Model } & \multicolumn{2}{|c|}{$\begin{array}{l}\text { Unstandardized } \\
\text { Coefficients }\end{array}$} & \multirow{2}{*}{$\begin{array}{l}\text { Standardized } \\
\text { Coefficients } \\
\text { Beta }\end{array}$} & \multirow[b]{2}{*}{$\mathrm{t}$} & \multirow[b]{2}{*}{ Sig. } \\
\hline & B & Std. Error & & & \\
\hline Constant) & 7.095 & 3.177 & & 2.233 & .029 \\
\hline X.1 & .409 & .193 & .228 & 2.116 & .038 \\
\hline X.2 & .637 & .126 & .540 & 5.052 & .000 \\
\hline X.3 & -.372 & .172 & -.190 & -2.164 & .034 \\
\hline
\end{tabular}

${ }^{\mathrm{a}}$. Dependent Variable: $\mathrm{Y}$

Processed sources of SPSS 
Based on the result of $t$ test which is done by comparing Probability sig value. any independent variable with a specified limit of 0.05 . From the comparison of P Sig. in Table 6, the value was 0,038 for the competence variable, 0.000 value for the independence variable and the value was 0.034 for the variable of workload which means is under the limit of 0.05 . At the level of real $\alpha=0.05$, competence, independence and workload have a partially significant effect on the dependent variable, ie audit quality, or in other words that at 5\% real level, the hypothesis stating that the competence, independence and workload partially significant effect on audit quality, proven true. Based on Table 6 also known regression equation formed as follows. $\mathrm{Y}=7.095+0.409 \mathrm{X} 1+0.637 \mathrm{X} 2-0.372 \mathrm{X} 3$

From this equation, it is seen that the quality of audit increase by 7.095 along with the fulfillment of competence of 0.409 ; independence was 0.637 and workload was -0.372 . From the equation can also be determined independent variables that have a dominant influence on the dependent variable which is seen from the highest regression coefficient value among independent variables, namely independence was 0.637 or greater than the coefficient of regression of competence variable was 0.409 and workload was -0.372 . The independence variable is the independent variable that has the most dominant influence on audit quality. Thus the hypothesis in this study proved true that states that independence has the most dominant influence on audit quality.

The value of partial coefficient (R) is 0.730 or $73 \%$. This value is positive and closer to 1 so it can be stated that there is a strong relationship unidirectional between independent variable, that is competence, independency and workload to dependent variable, that is audit quality.

The coefficient of determination serves as a measure of the accuracy or suitability of a type of regression to the observed data group $\mathrm{R}^{2}$ measures the proportion or percentage of total variation in $\mathrm{Y}$ as described by the regression model. In this research using three independent variables. Thus the measurement to know the contribution of independent variables to the dependent variable is based on the value of R Squared. Similarly, the value of the coefficient of determination that moves from 0 to 1 , $R$ Squared also shows the value of the closer to 1 then it means the better the contribution. The SPSS output shows the following results.

Table 7

Summary Model

\begin{tabular}{|l|c|c|c|c|}
\hline Model & $\mathrm{R}$ & R Square & $\begin{array}{c}\text { Adjusted } \\
\text { R Square }\end{array}$ & $\begin{array}{c}\text { Std. Error of } \\
\text { The Estimate }\end{array}$ \\
\hline 1 & $.730^{\mathrm{a}}$ & .533 & .510 & 3.377 \\
\hline
\end{tabular}

a. Predictors: (Constant), X2, X1

Processed sources of SPSS

In the calculation results that have been described before, the coefficient value of $\mathrm{R}$ Square was 0.533 shows a strong influence between the independent variable with the dependent variable (bound). The coefficient value was $53.3 \%$ indicates that this multiple regression model which independent variable consists of competence (X1), independence (X2) and workload (x3) has contributed $53.3 \%$ to the formation of dependent variable that is audit 
quality. While the rest of $46.7 \%$ is determined by other factors such as company size, time of work, internal control and so on.

The three independent variables showed significant effect on audit quality. First is the competence has a significant effect on audit quality. This is in accordance with the statement of Gul et al. (1994) which asserts that audits should be undertaken and reports prepared with professionals that are persons who have adequate training, experience and competence in the audit. With the competence of the auditors, the feasibility of an audit report can be accounted for.

Independence proved to have a significant effect on audit quality. This is in accordance with DeAngelo (1981) which states that independence is important in addition to the auditor's technical ability to determine audit quality. The value of Audit quality rely heavily on public perceptions of auditor independence (Arens and Loebbecke, 2012). In fact, especially investors are more concerned with factors of auditor independence. By showing independence, the auditors will meet the needs of investors to be able to obtain decision-making materials related to the prospects of the company in the future (Franzel 2012).

The third independent variable is the workload that has been shown to have a significant effect on audit quality. This is in line with the findings of Persellin et al. (2014) which states that the workload affects with the audit quality. Workload is something that is reasonable for every worker but it will affect the work if it is borne excessively. Effective division of labor and auditor rotation may be an alternative solution to the workload evenly shared by auditors in their respective offices.

\section{CONCLUSION}

Here are the findings of this research. There is a positive and partially significant influence between competence on audit quality. There is a positive and significant influence partially between independence on audit quality. There is a positive and partially significant influence between the workload on audit quality. There is a positive and significant influence simultaneously between competence, independence and workload on audit quality. Independence is a variable that has a dominant influence on audit quality.

\section{Refferences}

Arens, Alvin A \& Loebbecke, James K. (2012). Auditing, an Integrated Approach. 14th Edition. Upper Saddle River, New Jersey: Prentice-Hall, Inc.

Cordes, C.L., and T.W. Dougherty. (1993). A review and an integration of research on job burnout. Academy of Management Review 18: 621-656.

DeAngelo, L, E. (1981). Auditor Size and Audit Quality, Journal of Accounting and Economics, 3, 183-199

Deis, D.R. dan G.A. Groux. (1992). Determinants of Audit Quality in The Public Sector. The Accounting Review. Juli. p. 462-479.

Franzel, J. M. (2012). Driving change to achieve independent and high-quality audits. Keynote address to the Baruch College Financial Reporting Conference, May 3.Availableonlinea http://pcaobus.org/News/Speech/Pages/05032012_Baruch.aspx,retrieved 5/3/2012

Gul, Ferid A., Hai Y., Teoh, Beer Andrew H.,, and Schelluch P. (1994). Theory and Practice of Australian Auditing, Third Edition, Nelson, an International Thomson Publishing 
JARES, Vol. 2 No. 2 September, 2017; p-ISSN: 2502-826X; e-ISSN: 2503-1163

\section{Company, Australia.}

Hansen C. S, Kumar K.R And Sullivan M.W. (2007). Auditor Capacity Stress And Audit Quality: Market-Based Evidence From Andersen's Indictment. Journal of Accounting and Economics, 10-49

Ionescu, Luminita. (2016). The Impact of Rotation on Accounting and Audit Quality. Economics, Management, and Financial Markets, Vol. 11, Issue 3, 86-92.

Jackson, S.E., R.L. Schwab, and R.S. Schuler. (1986). Toward an understanding of the burnout phenomenon. Journal of Applied Psychology 71: 630 - 640

Kwanbo, Lubabah Mansur. (2009). Internal Control and the Issues of Independence \& Confidentiality in Nigerian Local Government Auditing: An Examination,

Lee, Tom. \& Mary Stone. (1995). Competence And Independence: The Congenial Twins Of Auditing?, Journal of Business Finace and Accounting, Volume 22, Issue 8, December, 1169-1177

Libby, Robert \& David M. Frederick. (1990). Experience and the Ability to Explain Audit Findings, Journal of Accounting Research Vol. 28, No. 2 (Autumn), pp. 348-367

Lopez-Acevedo, D. M. (2005). The Effect Of Workload Compression On Audit Quality. Working Paper, University Of Arkansas.

McKee, Annie. (2014). Being happy at work matters. Harvard Business Review, November

Persellin, J., J. J. Schmidt, \& M. S. Wilkins. (2014). Auditor perceptions of audit workloads, audit quality, and the auditing profession. Working paper, Trinity University and the University of Texas at Austin. 